Details of patients with primary biliary cirrhosis who later presented with extrahepatic malignancy

\begin{tabular}{|c|c|c|c|c|c|}
\hline \multirow[b]{2}{*}{$\begin{array}{c}\text { Case } \\
\text { No }\end{array}$} & \multirow[b]{2}{*}{ Sex } & \multicolumn{2}{|r|}{ Tumour } & \multicolumn{2}{|c|}{ Age at presentation (years) } \\
\hline & & Site & Type & $\begin{array}{l}\text { Primary biliary } \\
\text { cirrhosis }\end{array}$ & Malignancy \\
\hline 1 & & Breast & Carcinoma & 51 & 55 \\
\hline 2 & $\mathrm{~F}$ & Breast & Carcinoma & 43 & 51 \\
\hline 3 & $\mathrm{~F}$ & Breast & Carcinoma & 58 & 66 \\
\hline 4 & $\mathrm{~F}$ & Breast & Carcinoma & 67 & 76 \\
\hline 5 & $\mathrm{~F}$ & Breast & Carcinoma & 61 & 65 \\
\hline 6 & $\mathrm{~F}$ & Breast & Carcinoma & 47 & 51 \\
\hline 7 & $\mathrm{~F}$ & Bronchus & Large cell anaplastic carcinoma & 63 & 65 \\
\hline 8 & $\mathrm{~F}$ & Bladder & Transitional cell carcinoma & 62 & 71 \\
\hline 9 & $\mathrm{~F}$ & Cervix & Squamous carcinoma & 57 & 58 \\
\hline 10 & $\mathrm{~F}$ & Stomach & Adenocarcinoma & 57 & 60 \\
\hline 11 & $\mathbf{M}$ & Bronchus & Squamous carcinoma & 65 & 70 \\
\hline 12 & $M$ & Colon & Carcinoma & 67 & 71 \\
\hline 13 & $\mathbf{M}$ & Hodgkin's disease & & 53 & 54 \\
\hline
\end{tabular}

clinical and histological details. The incidence of carcinoma of the breast was significantly increased in women with primary biliary cirrhosis-that is, six cases observed compared with 1.59 expected $(p<0.0015)$. There was no excess of other extrahepatic tumours in patients of either sex.

\section{Discussion}

Our observation of an increased incidence of breast cancer in women with primary biliary cirrhosis corroborates the findings of
Wolke et al. ${ }^{2}$ Though close surveillance of hospital patients may result in increased detection of malignancy and produce erroneous evidence of an association with other disease, ${ }^{5}$ we think it unlikely that this phenomenon would result in the increased detection of breast tumours only.

The biological basis for an association between primary biliary cirrhosis and breast cancer is obscure, but defective immune surveillance, endocrine dysfunction, or deficiency of fat soluble vitamins may be implicated. We suggest that these factors should be examined in further studies of patients with primary biliary cirrhosis and that the frequency of extrahepatic malignancy should be investigated in patients with other forms of chronic liver disease.

This study was supported by a grant from the biomedical research committee of the Scottish Home and Health Department.

\section{References}

1 Mills PR, Boyle P, Quigley EMM, et al. Primary biliary cirrhosis: an increased incidence of extrahepatic malignancies? $\mathcal{f}$ Clin Pathol 1982;35:541-3.

2 Wolke AM, Schaffner F, Kapelman B, Sacks HS. Malignancy in primary biliary cirrhosis. Hig incidence of breast cancer in affected women. Am $\mathcal{J}$ Med 1984;76:1075-8.

3 Gillis CR, Boyle P, Hole DJ, Graham A. Scotland West Registry. In: Waterhouse JAH, Muir CS, Shammugaratnam K, Powell J, eds. Cancer incidence in five continents. Vol 4. Lyon: IARC Scientific Publications, 1982:592-5.

4 Hill ID. Computing man years of risk. British Journal of Preventive and Social Medicine 1972;26:132-4.

5 Berkson J. The statistical study of association between smoking and lung cancer. Proceedings of the Staff Meetings of the Mayo Clinic 1955;30:319-48.

(Accepted 5 September 1985)

\title{
Loss of pulsatile luteinising hormone secretion in men with chronic renal failure
}

\author{
R S C RODGER, L MORRISON, J H DEWAR, R WILKINSON, M K WARD, \\ D N S KERR
}

\begin{abstract}
In an attempt to determine the nature of hypothalamic and pituitary dysfunction in renal failure the secretory patterns of luteinising hormone were measured in men with end stage renal disease and compared with those in healthy controls and renal transplant recipients of similar age distribution. Mean luteinising hormone and oestradiol concentrations were significantly higher and the number of luteinising hormone secretory pulses was significantly lower in uraemic men compared with controls.
\end{abstract}

\footnotetext{
Departments of Medicine, Freeman Hospital and Royal Victoria Infirmary, Newcastle upon Tyne

R S C RODGER, MB, MRCP, lecturer

R WILKINSON, MD, FRCP, reader

M K WARD, FRCP, senior lecturer

Supraregional Assay Service, Royal Victoria Infirmary, Newcastle upon Tyne L MORRISON, AIMLF, medical laboratory scientific officer

J H DEWAR, PHD, principal hospital biochemist

Royal Postgraduate Medical School, London W12

D N S KERR, MSC, FRCP, dean

Correspondence to: Dr Rodger, Department of Medicine, Royal Victoria Infirmary, Newcastle upon Tyne NE1 4LP.
}

Plasma testosterone and oestradiol concentrations were significantly lower in renal transplant recipients than normal men, but there were no significant differences in mean gonadotropin concentrations or the number of pulses of luteinising hormone between the two groups. As pulses of luteinising hormone are thought to reflect episodic gonadotropin releasing hormone from the hypothalamus these data suggest that uraemia interferes with central mechanisms controlling synchronised release of gonadotropin releasing hormone. This defect appears to be reversible after successful transplantation.

\section{Introduction}

Testicular dysfunction as manifested by decreased libido, potency, and testicular size is well recognised in men with end stage renal disease. ${ }^{1}$ Plasma testosterone concentrations and rates of testosterone production are often low and there is diminished or absent spermatogenesis. ${ }^{2}$ These changes may be reversed and fertility restored after successful renal transplantation. ${ }^{3}$

The importance of pulsatile gonadotropin releasing hormone in the physiology of the male reproductive system has been shown by its therapeutic effect in the management of hypogonadotropic hypogonadism. ${ }^{+}$Secretion of pulsatile luteinising hormone itself is thought to be important to allow gonadotropin receptors in the testes to be maintained as sustained high concentrations lead to loss of receptors. ${ }^{56}$ In this study the secretory patterns of luteinising 
hormone were measured in men with renal failure and compared with those in men with functioning renal transplants and normal controls.

\section{Patients and methods}

Six men with end stage renal disease of mean age 28 (range 20-34) years were studied; three were being treated with continuous ambulatory peritoneal dialysis and three with intermittent haemodialysis. Their mean duration of renal replacement treatment was 43 (eight to 72) months. Six men of mean age 31 (26-41) years, with functioning renal allografts (plasma creatinine concentration $<200 \mu \mathrm{mol} / 1(<2.3 \mathrm{mg} / 100 \mathrm{ml})$ ) 17 (six to 35 ) months after transplantation were also studied. All were first graft recipients receiving prednisolone and azathioprine, and their mean duration of dialysis before transplantation was 24 (seven to 40 ) months. Six male volunteers recruited from hospital and university staff of mean age 29 (27-31) years with no history of endocrine or renal disease formed the control group. In addition, one patient in the renal control group was restudied five months after successful renal transplantation.

The subjects were admitted overnight, and an indwelling cannula for sampling was inserted under local anaesthesia. From 6 am to 10 am samples were taken every 10 minutes for estimation of serum luteinising hormone concentration. Concentrations of serum prolactin and follicle stimulating hormone, plasma testosterone, $17 \beta$ oestradiol, and sex hormone binding globulin were also measured.

Luteinising hormone and follicle stimulating hormone were measured by standard radioimmunoassay using liquid phase second antibody separation with reagents supplied by the endocrine department, the Chelsea Hospital for Women, London (World Health Organisation standards 68/40 and 78/549). Samples from each subject for measurement of luteinising hormone concentrations were analysed in duplicate in one assay. Intrabatch and interbatch coefficients of variation for luteinising hormone were $6.2 \%$ and $8 \%$, respectively. A luteinising hormone pulse was defined as an increment in luteinising hormone concentration from nadir to peak of greater than $20 \%$ in two or more consecutive samples. ${ }^{78}$

Prolactin was measured by radioimmunoassay using the Medical Research Council interim standard reference $81 / 541$, supplied by the North East Thames regional immunoassay unit, St Bartholomew's Hospital, London, and antiserum produced by Immuno Nuclear Corporation (United States), supplied by RIA (United Kingdom), Washington, Tyne and Wear. Sex hormone binding globulin concentration was measured by a modification of the method of Rosner, ${ }^{9}$ with intrabatch and interbatch coefficients of variation of $2 \cdot 5 \%$ and $11.7 \%$ at $35 \mathrm{nmol} / 1$ and $41 \mathrm{nmol} / 1$, respectively. Testosterone and $17 \beta$ oestradiol concentrations were measured by direct radioimmunoassay (RSL Inc, Carson, California, USA, and SB ESTR International-Cis, St Quenton-Yuelines, France) with intrabatch and interbatch coefficients of variation of $6.2 \%$ and $5.5 \%$ for testosterone at 12.5 $\mathrm{nmol} / \mathrm{l}$ and $12.0 \mathrm{nmol} / 1(3.6 \mathrm{ng} / \mathrm{ml}$ and $3.5 \mathrm{ng} / \mathrm{ml})$, respectively. The interbatch coefficient of variation for $17 \beta$ oestradiol was $17 \cdot 3 \%$ at $158 \mathrm{pmol} / 1$ $(43 \mathrm{pg} / \mathrm{ml})$ and $7 \%$ at $1068 \mathrm{pmol} / \mathrm{l}(291 \mathrm{pg} / \mathrm{ml})$.

Statistical analyses were performed using the Student's $t$ test and the Wilcoxon rank sum test.

\section{Results}

Mean luteinising hormone concentrations were higher and the number of secretory pulses of luteinising hormone was significantly lower in men with renal failure compared with renal transplant recipients or healthy subjects (table). There were no significant differences between the groups in the amplitude of secretory pulses. Secretion of pulsatile luteinising hormone was observed in all controls and transplant recipients studied but in only one patient with renal failure. Figure 1 shows typical secretory patterns from each group. A return to normal pulsatile release of luteinising hormone was observed in the patient who was studied before and after renal transplantation (figure 2).

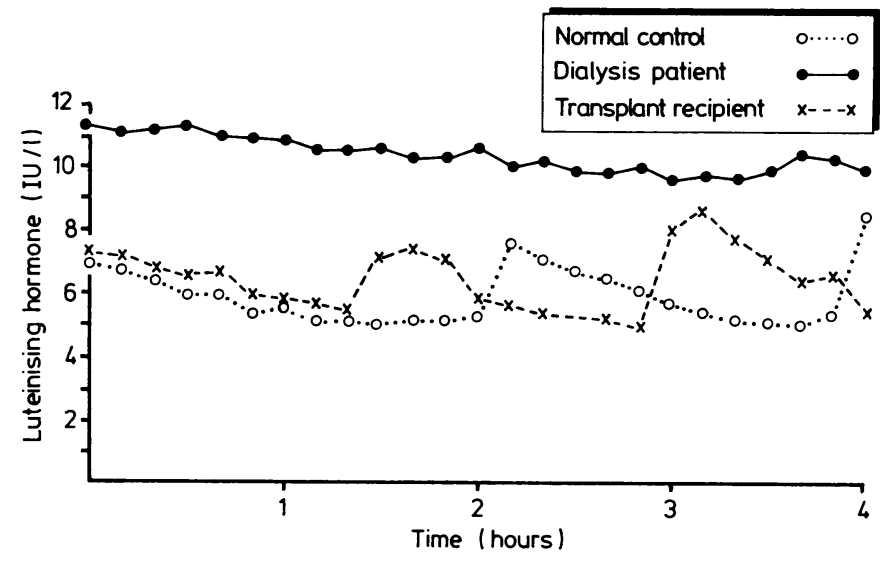

FIG 1-Luteinising hormone secretory pattern in three subjects (one from each group).

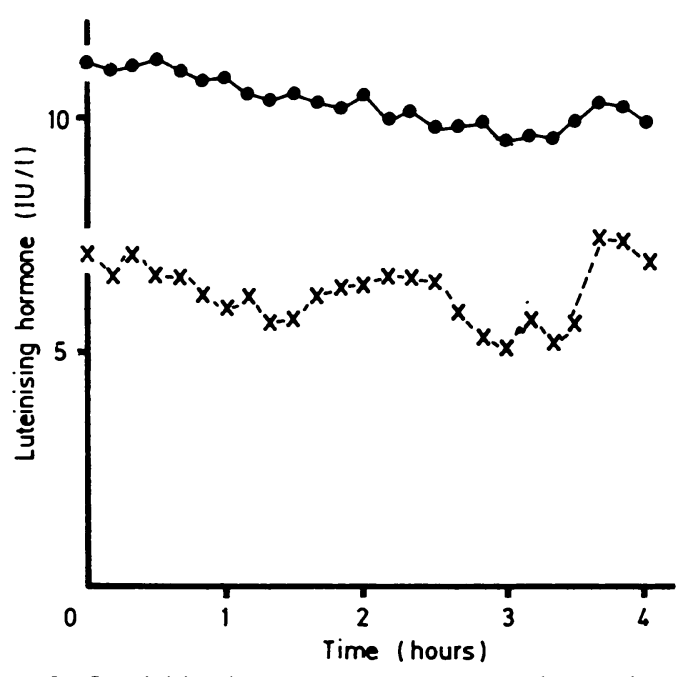

FIG 2-Luteinising hormone secretory pattern in a patien before $(\bullet-\bullet)$ and after $(x-x)$ transplantation.

Plasma testosterone concentrations in uraemic men did not differ from those in controls, but $17 \beta$ oestradiol concentrations were increased significantly. Both plasma testosterone and oestradiol concentrations were significantly reduced in transplant recipients compared with controls and men with renal failure. Sex hormone binding globulin concentrations were higher in men with renal failure than transplant recipients or controls, though the difference between men with renal failure and controls did not reach significance (table).

Hormone profiles and analysis of luteinising hormone pulses

\begin{tabular}{|c|c|c|c|c|c|c|c|c|}
\hline & $\begin{array}{c}\operatorname{Mean}(\mathrm{SD}) \\
\text { luteinising hormone } \\
\mathrm{U} / 1\end{array}$ & $\begin{array}{c}\text { Frequency of } \\
\text { luteinising hormone } \\
\text { pulses } \\
\text { (episodes } / 24 \mathrm{~h} \text { ) }\end{array}$ & $\begin{array}{l}\text { Amplitude of } \\
\text { luteinising } \\
\text { hormone } \\
\text { pulses U/1 }\end{array}$ & $\begin{array}{l}\text { Mean }(\mathrm{SD}) \\
\text { testosterone } \\
\text { nmol/1 }\end{array}$ & $\begin{array}{c}\text { Mean (range) } \\
\text { sex hormone } \\
\text { binding globulin } \\
\text { nmol/1 }\end{array}$ & $\begin{array}{l}\text { Mean }(S D) \\
\text { oestradiol } \\
\text { pmol/l }\end{array}$ & $\begin{array}{l}\text { Mean (range) } \\
\text { follicle stimulating } \\
\text { hormone } U / 1\end{array}$ & $\begin{array}{l}\text { Mean (SD) } \\
\text { prolactin } \\
\text { mU/l }\end{array}$ \\
\hline $\begin{array}{l}\text { Group I: men with renal failure }(n=6) \\
\text { Difference between groups I and II } \\
\text { Group II: normal men (controls) }\end{array}$ & $\begin{array}{l}12 \cdot 5(5 \cdot 7) \\
\mathrm{p}<0.05\end{array}$ & $\stackrel{1}{p<0 \cdot 01}$ & $\begin{array}{l}2 \cdot 9 \\
\text { NS }\end{array}$ & $\begin{array}{l}20 \cdot 3(8 \cdot 2) \\
\quad \text { NS }\end{array}$ & $\begin{array}{l}43 \cdot 2(29-72) \\
\text { NS }\end{array}$ & $\begin{array}{l}278(90) \\
p<0.05\end{array}$ & $\begin{array}{c}4 \cdot 1(1 \cdot 8 \cdot 13 \cdot 7) \\
\text { NS }\end{array}$ & $\begin{array}{c}363(106) \\
\text { NS }\end{array}$ \\
\hline $\begin{array}{l}(\mathrm{n}=6) \\
\text { Difference between groups II and III } \\
\text { Group III: men with renal transplants }\end{array}$ & $\begin{array}{l}5 \cdot 7(2 \cdot 4) \\
\quad \mathrm{NS}\end{array}$ & $\begin{array}{c}12 \\
\text { NS }\end{array}$ & $\begin{array}{l}2 \cdot 3 \\
\text { NS }\end{array}$ & $\begin{array}{l}19 \cdot 6(4 \cdot 6) \\
\mathrm{p}<0.01\end{array}$ & $\begin{array}{l}32 \cdot 8(27 \cdot 42) \\
\text { NS }\end{array}$ & $\begin{array}{l}164(48) \\
p<0.05\end{array}$ & $\begin{array}{l}2 \cdot 6(0 \cdot 9-4 \cdot 6) \\
\text { NS }\end{array}$ & $\begin{array}{l}253(88) \\
\text { NS }\end{array}$ \\
\hline $\begin{array}{l}(n=6) \\
\text { Difference between groups I and III }\end{array}$ & $\begin{array}{l}6 \cdot 4(3 \cdot 0) \\
\text { NS }\end{array}$ & $\begin{array}{c}9 \\
\mathrm{p}<0.01\end{array}$ & $\begin{array}{l}2 \cdot 6 \\
\text { NS }\end{array}$ & $\begin{array}{l}9 \cdot 3(1 \cdot 2) \\
\mathrm{p}<0.05\end{array}$ & $\begin{array}{c}29.5(27-33) \\
\mathrm{p}<0.05\end{array}$ & $\begin{array}{l}97(31) \\
\mathrm{p}<0.01\end{array}$ & $\begin{array}{l}5 \cdot 3(2 \cdot 2-9 \cdot 3) \\
\text { NS }\end{array}$ & $\begin{array}{l}313(256) \\
\quad \text { NS }\end{array}$ \\
\hline
\end{tabular}

Conversion: SI to traditional units-Testosterone: $1 \mathrm{nmol} / 1 \approx 0.29 \mathrm{ng} / \mathrm{m}$

Oestradiol: $1 \mathrm{nmol} / \mathrm{l} \approx 272 \mathrm{pg} / \mathrm{ml}$. 


\section{Discussion}

In normal men, as seen in the control group of this study, pulses of luteinising hormone release occur at $90-130$ minute intervals in an intermittent non-cyclic pattern. ${ }^{7}$ Pulses of luteinising hormone are believed to reflect episodic release of gonadotropin releasing hormone from the hypothalamus mediated by $\alpha$ adrenergic stimulation. ${ }^{11}$ Previous studies have shown that the basal concentrations of gonadotropins and gonadotropin releasing hormone are often raised in renal failure ${ }^{1-312}$ and the response of luteinising hormone to clomiphene or exogenous gonadotropin releasing hormone may be exaggerated, suggesting increased pituitary sensitivity. ${ }^{13}{ }^{14}$

The raised oestradiol concentrations present in the dialysis group in this study may have had a modulating role on the pulsatile release of luteinising hormone as oestrogen administered to normal men causes a reduction in pulse amplitude though without influencing pulse frequency. ${ }^{\text {is }}$ Secretory pulses of luteinising hormone may also be attenuated by prolactin,${ }^{8}$ although there were no significant differences between the groups in mean prolactin concentrations and only one patient studied, who was a transplant recipient, had a raised serum prolactin concentration.

The steroid hormone patterns observed in the three groups studied were different, but measurements of free or unbound hormone were not performed. Concentration of sex hormone binding globulin is increased in men undergoing dialysis, resulting in reduced free testosterone concentrations. ${ }^{16}$ In our study total testosterone concentrations were normal in men with renal failure, but the free testosterone concentrations may have been reduced as sex hormone binding globulin concentrations were increased (because of the small number of patients this difference was not significant). Previous studies have also noted raised oestradiol concentrations in uraemic men, but it is not known if this is due to increased testicular secretion, increased peripheral synthesis, reduced clearance, or changes in sex hormone binding globulin concentrations..$^{14} 17$

In the group of transplant recipients libido and potency increased in most after the return of normal renal function despite reduced testosterone concentrations, and fertility was restored in at least two patients who subsequently fathered children. Previous reports have noted low testosterone concentrations after transplantation, ${ }^{18}$ but the finding of reduced oestradiol concentrations contrasts with the report by Handelsman $e t$ al in which oestrogen concentrations were normal. ${ }^{19}$ The reduction in steroid hormone concentrations in transplant recipients could be partly explained by prednisolone treatment, which reduces plasma testosterone concentrations in asthmatics ${ }^{20}$ and sex hormone binding globulin concentrations. ${ }^{21}$

A primary testicular defect due to unidentified uraemic toxins has been proposed to explain the pattern of hypothalamic, pituitary, and testicular dysfunction in renal failure. ${ }^{22}$ Our findings do not support this view as men with primary testicular failure have normal or exaggerated luteinising hormone pulses. ${ }^{23}$ The relevance, however, of the loss of pulsatile luteinising hormone secretion in uraemia and its restoration after successful renal transplantation to the sexual function of men with renal failure is at present unknown.

We thank Carol Mullen and Elaine Gaiger, who measured plasma oestradiol and sex hormone binding globulin concentrations, and Carole Shipley, who typed the manuscript.

\section{References}

1 Chen JC, Vidt DG, Zom EM, Hallberg MC, Wieland RG. Pituitary-leydig cell function in uremic males. $\mathcal{I}$ Clin Endocrinol Metab 1970;31:14-9.

2 Holdsworth S, Atkins RC, De Kretser DM. The pituitary testicular axis in men with chronic rena failure. N Engl f Med 1977;296:1245-9.

3 Lim VS, Fang VS. Gonadal dysfunction in uremic men. A study of the hypothalamic-pituitarytesticular axis before and after transplantation. Am f Med 1975;58:655-62.

4 Donald RA, Wheeler M, Sonksen PH, Lowiz C. Hypogonadotropin hypogonadism resistant to hCG and responsive to LHRH. Clin Endocrinol 1983;18:385-9.

5 Hsurch AJ, Dufan ML, Catt KJ. Regulation of luteinising hormone receptors in testicular interstitial cells by gonadotropin. Biochem Biophys Res Commun 1976;72:1145-52.

6 Catt KJ, Harwood JP, Clayton RN, et al. Regulation of peptide receptors and gonadal steroidogenesis. Recent Prog Horm Res 1980;37:557-622.

Santen RJ, Bardin CW. Episodic luteinizing hormone secretion in man. $\mathcal{J}$ Clin Invest 1973;52:2617-28.

8 Winters $\mathrm{SJ}$, Troen $\mathrm{P}$. Altered pulsatile secretion of luteinising hormone in hypogonadal men with hyperprolactinemia. Clin Endocrinol 1984;21:257-63.

9 Rosner W. A simplified method for the quantitative determination of testosterone-oestradio binding globulin activity in human plasma. $\mathcal{F}$ Clin Endocrinol Metab 1972;34:983-8.
bestion

10 Carmel PW, Araki S, Ferin M. Pituitary stalk portal blood collection in rhesus monkeys: Carmel PW, Araki S, Ferin M. Pituitary stalk portal blood collection in rhesus monkeys
evidence for pulsatile release of gonadotropin releasing hormone. Endocrinology 1976;99:243-8 11 Bhallacharya AN, Dierschke DJ, Yamazi T, Khobile E. The pharmacologic blockade of the circhoral mode of LH secretion in the ovariectomised rhesus monkey. Endocrinology 1972;90: 778-86.

12 Matsubara M, Nakagawa K, Nonomura K, Kirota N. Plasma LRH levels in chronic renal failure before and during hemodialysis. Acta Endocrinol 1983;103:145-50.

13 Distiller LA, Morley JE, Sagel J, Pokroy M, Rabkin R. Pituitary gonadal function in chronic rena failure: the effect of luteinising hormone releasing hormone and the influence of dialysis. Metabolism 1975;24:711-20.

14 Lim VS, Fang VS. Restoration of plasma testosterone levels in uremic men with clomiphene citrate. $\mathcal{F}$ Clin Endocrinol Metab 1976;43:1370-7.

15 Santen RJ. Is aromatization of testosterone to oestradiol required for inhibition of luteinising hormone secretion in men? I Clin Invest 1975;56:1555-63.

16 Semple CG, Beastall GH, Henderson IS, Thomson JA, Kennedy AC. The pituitary testicular axis of uraemic subjects on haemodialysis and continuous ambulatory peritoneal dialysis. Acto of uraemic subjects on hae

17 Morley JE, Distiller LA, Pokroy M. Hormonal profiles in renal failure. S Afr Med f 1975;49: 474-9.

18 Morley JE, Distiller LA, Unterhalter S, Myers JB, Rabkin R, Katz M. Effect of renal transplantation on pituitary gonadal function. Metabolism 1978;27:781-5.

19 Handelsman DJ, Ralec VL, Tiller DJ, Horwath JS, Turtle JR. Testicular function after renal transplantation. Clin Endocrinol 1981;14:527-38.

20 Reid IR, Ibbertson HK, France JT, Pybus J. Plasma testosterone concentrations in asthmatic me treated with glucocorticoids. Br Med f 1985;291:574.

21 Vermeulen A, Verdouck L, Van der Straaten M, Orie N. Capacity of the testosterone binding globulin in human plasma and influence of specific binding of testosterone on its metabolic clearance rate. Clin Endocrinol 1981;14:527-38.

22 Stewart-Bentley M, Gans D, Horton R. Regulation of gonadal function in uremia. Metabolism 1974;23:1065-72.

23 Winters SJ, Troen $\mathrm{P}$. A re-examination of pulsatile luteinising hormone secretion in primary testicular failure. $f$ Clin Endocrinol Metab 1983;57:432-5.

(Accepted 24 September 1985)

\section{YEARS AGO}

Dr E. J. Miles of Brighton writes:-As the subject of position during labour is occasionally discussed in medical periodicals, and referred to in works on midwifery, it may not be without interest to some of your readers to give them some recent evidence on the subject as to the custom existing in ancient Rome. Several marble sarcophagi have just been discovered a few yards within the modern Porta Salaria at Rome. They were found about twentyfive feet below the present level of the ground, and in a position indicating the usual site of the hypogeum of an ancient tomb. On the face of the most beautiful one (considered, on the best authority, to be the work of the third century A.D., or earlier) are depicted, in the finest style of Greek art ever beheld, scenes representing the Triumph of Bacchus. Leaving the details to be read in the graphic letters of the Times correspondent at Rome, I would direct your readers' attention to the left-hand corner of the frieze (which is devoted to details connected with the birth of Bacchus), where, in a space measuring about twelve inches in height and twenty-three inches in length, is represented the moment immediately following the birth of the infant god. Whereas, in Italy and some other countries in the present day, the mother, during parturition, lies on her back, the goddess-mother Semele is here shown to be lying on her left side, as is the practice with us. She lies on a bed or couch, with the face and body directed towards the spectator, in an attitude of exhaustion, with her hands and arms hanging helplessly over the side of the couch, and directly beneath them a basin of similar shape to the ordinary English ewer. Immediately behind, is seen the accoucheur (a female), about to hand the newly born god to an attendant, and close at hand are the figures of other female attendants; and it may be noted, what is so often observed by us in the present day, that, whereas the greatest interes and attention is being exhibited towards the new-born child, the mother at that moment is lying altogether unnoticed. Mercury stands close to the head of Semele's couch; but, regardless of her, the messenger of the gods is awaiting with evident interest to carry off the infant to Jupiter. These sarcophagi are still in situ where they were recently discovered; and I should not have been able to see them, excepting through the auspices of the British Archæological Society at Rome, the meetings of which all visitors to Rome, having any real interest in archæology, should not fail to attend.

(British Medical fournal 1885;ii:612.) 